\title{
The Significance of Working Time Arrangements Accompanying the Introduction of Teamworking: Evidence from Employees
}

\author{
Nicolas Bacon, Paul Blyton and Ali Dastmalchian
}

\begin{abstract}
A study is reported where the introduction of teamworking was accompanied by negotiated changes in working time patterns, involving some employees transferring to a 5-shift, 8-hour pattern, others to a 5-shift, 12-hour pattern. Employee attitude surveys before and after the changes show those moving to 12-hour working much more satisfied with both working time and other changes, compared with those remaining on 8-hour shifts. The creation of extra non-work days was seen as the major advantage of the longer shifts, which compensated for the harder work regime identified under teamworking and the greater rigidity of the 5-shift system. The findings underline the potential significance of working hours for employee support for broader changes in working practices. Possible explanations of why the longer shift pattern met with considerable support at one research site, but failed to gain support at a similar site elsewhere, are also explored.
\end{abstract}

\section{Introduction}

Previous studies have underlined the importance of both the absolute length of working hours and aspects of working time arrangements for employees' overall well-being and job satisfaction (for a review, see Sparks et al. 1997; see also Clark and Oswald 1996). Within this literature, attention has been drawn to the importance of employees perceiving a sense of choice or discretion over elements of working time such as the design of their shift system, start and stop times, autonomy over when paid leave is taken and an ability

Nicolas Bacon is at Nottingham University Business School, Nottingham, UK. Paul Blyton is at Cardiff Business School, Cardiff University, Wales, UK. Ali Dastmalchian is at the University of Victoria, Canada. 
to make adjustments at short notice to accommodate other responsibilities and interests (see, for example, Berg 1999; Gray and Tudball 2003; Kogi and Di Martino 1995; Latack and Foster 1985; Smith et al. 1995). In his study of steelworkers in the United States, for example, Berg (1999) found that having a sense of discretion over working time - such as an ability to arrive late or leave early to take care of non-work responsibilities, having arranged this informally with the supervisor, or more formal procedures for taking time off work to deal with family matters - was a significant influence on overall job satisfaction. In particular, those workers who believed that their employer helped them to balance work and family responsibilities had a significantly higher probability of reporting being very satisfied with their jobs (ibid.: 127, 130).

Gareis and Chait Barnett (2002) similarly found that levels of psychological distress among female doctors in dual-earner couples were significantly less where respondents perceived that the distribution and flexibility of their working hours allowed them to fulfil their own, and their family's non-work needs. This degree of 'schedule fit' was a more significant variable than the overall number of working hours in explaining respondents' experience of psychological distress. Consistent with this, other studies (for example, Gray and Tudball 2003) identify discretion over working time - such as the degree of control over start and finish times - as central to the presence of familyfriendly work practices (see also Dex 1999).

This evidence of the importance of schedule fit and perceived discretion or choice over, for example, work start and stop times, may be seen as part of the broader recognition of the importance that employees attach to exerting control in, and over, the working period - for example, in relation to access to paid overtime, the maintenance of informal breaks, the prevalence of organized absence in some settings, and the use of speed-ups and slow-downs to create a degree of temporal autonomy (for a review of issues surrounding the control of working time, see Noon and Blyton 2002: 79-93). The recognized importance of perceived flexibility over working time also adds a further dimension to other recent studies of employees' working time preferences that have tended to focus on preferences towards the quantity of working hours and attitudes to different working time schedules (see, for example, Stewart and Swaffield 1997; Stier and Lewin-Epstein 2003). In practice, employee preferences over working time schedules relate both to the quantity and the arrangement of working hours.

Employers, too, have increasingly recognized the cost and operational significance of different working time arrangements. The factors behind this greater recognition are various, and include increased attention being given to reducing premium-paid overtime working, the need to arrange work schedules to cover extended opening/operating times, and a desire to increase the degree of temporal flexibility (again, without incurring large overtime costs) (Blyton 1994). Ways in which employers have sought to reduce overtime costs, while at the same time staff extended or continued operations, have been through the use of extended shifts and the introduction of annual hours 
contracts, whereby the hours of employees are calculated on an annual rather than a weekly basis. In principle, such contracts allow variation of work patterns to match fluctuations in demand. In this way, one aim of such systems is to facilitate greater forward planning of work rosters, thereby, in theory at least, reducing reliance on overtime working (Blyton 1994, 1995; IDS 2002). However, the greater flexibility for employers offered by annual hours and other shift changes to match consumer and employer demand for labour imply unpredictability and uncertainty for employees, and may have negative effects on job satisfaction, employee commitment and labour turnover if they do not match employees' working time preferences (Casey et al. 1997; Purcell et al. 1999).

In some countries, most notably the UK and Australia, a significant proportion of annual hours systems have been introduced on the basis of 12-hour shiftworking. This association between annual hours contracts and 12-hour shifts has contributed to a growing incidence of 12-hour working in these countries, to the point where, in the UK, for example, 12 hours is the most common shift length after eight hours (Smith et al. 1998b: 275). In Australia, the relative lack of regulation over working periods, the decentralization of collective bargaining arrangements and employers' desire to increase productivity and reduce costs have each been identified as factors stimulating the expansion of the 12-hour work pattern (Heiler 1998; Loudoun and Harley 2001; Nelson and Holland 2001; see also Campbell 2002). As Loudoun and Harley (2001) point out, for employers, 12-hour shifts offer potentially greater continuity (fewer shift handovers) and increased coverage of operations via 'standard' rather than premium paid hours (see also Lowden et al. 1998). Elsewhere, particularly in North America, the growth of extended hours over the past two decades has also been evident (Bluestone and Rose 2000; Golden and Figart 2000). The practice of compressing the work week into fewer than five days, through the use of longer shift lengths, is also well-established in North America, although it has attracted little research attention in recent years (Latack and Foster 1985; Pierce and Dunham 1992; Ronen and Primps 1981).

For employees, the main potential benefit of extended working, such as 12hour shifts, lies in the compressed work-week effect, with fewer shifts being worked per annum, and correspondingly less travelling to and from work and more non-work days in which to engage in social and domestic activities. Various studies in several national contexts, and involving different occupational groups, have identified satisfaction with non-working time as the major perceived benefit of 12-hour shifts (see, for example, Goodale and Aagard 1975; Kaliterna and Prizmić 1998; Lowden et al. 1998; Milia 1998; Mitchell and Williamson 2000; Nord and Costigan 1973; Ronen and Primps 1981; Smith et al. 1998a; Wallace 1998). In part, this may be because 12-hour rosters can yield free time that, because of its length or timing, is perceived to be of higher value than the free time available to those working 8-hour shifts (Baker et al. 2003). Other studies have examined the potential drawbacks of the longer shifts, particularly on aspects of individual behaviour such

(C) Blackwell Publishing Ltd/London School of Economics 2005. 
as fatigue, alertness, stress, sleep pattern, performance and accident levels (see, for example, Iskra-Golec et al. 1996; Milia 1998; Mitchell and Williamson 2000; Ognianova et al. 1998; Rosa 1995). Overall, 12-hour shifts emerge surprisingly well from these studies, with little evidence of anticipated differences in such factors as fatigue, accident rates and performance levels when comparing those on 12-hour and 8-hour patterns.

There have been far fewer studies, however, of the role that working time arrangements may play in employee response to broader work organization change programmes, where working time is one of a number of aspects of change. Berg's (1999) study discussed earlier suggests that aspects of working time can exert a significantly broader influence on employee attitudes than simply attitudes to the working time pattern. Berg examined employee responses to the introduction of a number of 'high performance' work practices (in particular teamworking, informal learning, formal training and worker communication practices) and revealed the important mediating effect of satisfaction with the working time system. Other studies have pointed to a generalization of positive working time attitudes to broader job attitudes (Latack and Foster 1985; Ronen and Primps 1981), although such relationships have not always been identified (for example, Pierce and Dunham 1992).

The role of working time changes to support 'high performance' work practices is an important area of study because intense competition in many industries continues to encourage managers to introduce these practices to improve workplace performance and turn round struggling firms. However, the requirement to restructure and reduce costs has pressurized employees into accepting new practices and conceding staffing reductions without a compensating increase in earnings (Handel and Levine 2004). In such cases, employees may still respond positively to the redesign of work if it provides increased autonomy and enriched jobs, with a positive impact on intrinsic job satisfaction (Appelbaum et al. 2000; Patterson and West 1998; Steijn 2001; Wall et al. 1986). However, teamworking can also lead to greater work intensity and stress (Anderson-Connolly et al. 2002; Parker and Slaughter 1994; Rinehart et al. 1997) where employers are pressurized by competitive markets to elicit greater effort from employees. The effects of teamworking on employee attitudes, therefore, depend on the different organizational contexts and how teams are introduced (Harley 2001; Hunter et al. 2002; Marchington 2000). Changes to working time offer the potential to recompense employees for an increase in work pressure when teams are introduced in firms and where the requirement to reduce costs prevents managers from increasing employee earnings in return for teamworking.

It is this potentially broader significance of working time patterns for employee attitudes that was of central interest in the present study. In an investigation of the negotiation and introduction of a major work reorganization programme in two integrated iron and steel plants - a reorganization focused on the introduction of teamworking - we were able to study reactions to different changes in working time arrangements. For, while all the areas of iron and steelmaking and finishing underwent a change to 
teamworking and simultaneously moved from a 4 - to a 5 -shift system, in some areas this was introduced in conjunction with a negotiated change from 8- to 12-hour working, while in others the new 5 -shift system was introduced with the agreed retention of an 8-hour pattern. Thus, we were able to assess employee responses to the new working time patterns as part of a broader longitudinal investigation of responses to the introduction of teamworking.

\section{The research sites}

In 1998, the authors commenced a longitudinal investigation into the introduction of teamworking at two major integrated steelworks in the north of England (Teesside and Scunthorpe) belonging to Corus, the Anglo-Dutch iron and steel manufacturer. All stages of iron and steelmaking are undertaken at each of the two plants from the import of raw materials through dock facilities, to iron and steelmaking and various finishing activities in different rolling mills. The two plants are similar in size and range of operations and together formed a division of the company under the same senior management team.

\section{The Change to Teamworking}

The introduction of teamworking in all areas of production involved all shopfloor workers with changes in job content, job grades and working time systems. Former occupational hierarchies based on seniority, along with distinctions between craft and production workers, were replaced by a system based on management selection of team leaders and the integration of many former maintenance craft workers into production teams. Teams became responsible for all aspects of production, together with inspection, day-to-day maintenance and resolving the majority of breakdowns in their areas. Although negotiations in each department decided the precise detail of teams, senior managers ensured the structure of teams was identical across the two plants by establishing a common blueprint in site wide agreements.

\section{The Working Time System}

The production of iron and steel, along with many of the finishing activities, are undertaken on a continuous, round-the-clock basis (coke ovens, blast furnaces and steel converters, in particular, once heated, need to be operated continuously until major maintenance or repairs are required). At the sites under investigation, prior to teamworking, employees worked for eight hours on a 4-shift system and shift workers enjoyed a significant degree of choice over when they could take their holidays. Teamworking was accompanied by the introduction of a continuous 5-shift system to replace a 4-shift system. Under the 5-shift system all non-work days, including holidays, form part of the shift roster (that is, holidays and other days off became fixed). 
Under the new 5-shift system, an 8-hour shift length continued at one of the plants (Scunthorpe). Scunthorpe employees, reorganized into teams, worked a rota pattern of six shifts, followed by two rest days, with a long rest break of 16 days every 10 weeks. These ' 6 on 2 off' rotas also involved a 'quick return' from nights to afternoons (two mornings, two nights, two afternoons, followed by two days off).

In contrast to the Scunthorpe plant, across all but one department at the Teesside works, the adoption of the 5-shift system was accompanied by negotiated agreements to move from 8- to 12 -hour working - thus, to a 5shift, 12-hour pattern. Typically, employees worked four shifts of 12 hours followed by four days off (' 4 on 4 off'); this was concluded by an 18-day break after working 40 shifts. For many employees at the Teesside plant this involved working a basic year of 147 shifts, far fewer than under the previous 8-hour system. Like their Scunthorpe counterparts on 8-hour shifts, those on 12 hours had an annual hours contract based on an agreed $36^{1} / 2$-hour working week. Thus, when teamworking was introduced the main difference in working time between the two sites was that employees at Scunthorpe had two days off after every six days of 8-hour shifts, whereas Teesside employees had four days off after working four days of 12-hour shifts.

\section{Fieldwork}

The fieldwork conducted for the research had three principal components. First, two large-scale employee attitude surveys were conducted. The first of these was undertaken in 1999, immediately prior to the introduction of teamworking and shift system changes, while the second was undertaken in 2002, following the introduction of teamworking and the 5-shift system in all departments. Both surveys were administered to all employees, were posted to their homes and returned directly to the university. They were supported in each case by the trade unions and the plant management (both parties providing covering letters of support which accompanied the mailed questionnaires). In 1999, a survey distribution of 9,000 resulted in 2,802 replies, a response rate of 31 per cent. In 2002 (and following a significant reduction in workforce totals at the two plants during the intervening period), a distribution of 7,041 surveys resulted in 2,060 replies, a response rate of 29 per cent. The longitudinal data is, therefore, derived from repeat cross-section surveys rather than collected from exactly the same individuals. A comparison of the two survey sets, together with a comparison with personnel records, indicates that the survey respondents were comparable in terms of response rates for site, department and grade. The sample is an exclusively male manufacturing workforce, 66 per cent had worked for the company for over 20 years, with 40 per cent between 40-49 years of age, and 24 per cent aged 5059. The longitudinal surveys contained two questions relating to satisfaction with working time (satisfaction with 'your overall hours of work' and 'your rota pattern'), and a question on overall job satisfaction (Warr et al. 1979). 
Other questions measured perceptions of work pressure (Andries et al. 1996) at both survey periods, together with respondents' overall attitude to teamworking. An open-ended question inviting further comment was also included at the end of both surveys.

Second, an interview programme was conducted with managers and union representatives involved in the negotiation of teamworking and other changes at plant and departmental levels; a total of 47 in-depth interviews were undertaken. Third, extensive documentary analysis of departmental teamworking agreements was undertaken. Among other things, these agreements contained details of shift rotas to accompany teamworking.

\section{Results}

\section{Satisfaction with the Working Time Pattern}

Overall, comparing survey responses in 2002 with 1999, respondents in Teesside departments moving to 5-shift, 12-hour working showed an increase in satisfaction with different aspects of their working hours, compared with those at Scunthorpe changing to five shifts and remaining on eight hours. This was evident in relation to satisfaction both with 'overall hours of work' and 'the rota pattern' (satisfaction was measured on a 7-point response scale ranging from 'extremely satisfied' to 'extremely dissatisfied'). Between 1999 and 2002, at the Teesside plant (which moved to 12-hour shifts, with one departmental exception; see below), the percentage of employees satisfied with first, the overall working hours, increased from 52 per cent to 63 per cent and second, with the rota pattern, increased from 48 per cent to 68 per cent. Increased satisfaction with both overall working hours $(t=4.111, p<0.001)$ and the rota pattern $(t=10.023, p<0.001)$ were statistically significant. In contrast, at the Scunthorpe plant (remaining on 8-hour shifts), the percentage of employees satisfied with overall working hours declined from 60 per cent to 54 per cent and satisfaction with the rota pattern declined from 65 per cent to 56 per cent. Declining satisfaction at Scunthorpe was statistically significant for both overall working hours $(t=-3.530, p<0.001)$ and the rota pattern $(t=-6.281, p<0.001)$. As a result, while the two plants were not significantly different from one another on either of these working time satisfaction items in 1999, by 2002 respondents at the two plants were highly significantly different from one another in relation both to overall hours of work $(t=-3.933, p<0.001)$ and the rota pattern $(t=-8.562, p<$ 0.001 ) with the Teesside plant moving to 12 -hour working reporting higher levels of satisfaction on both items.

A more detailed departmental comparison of employee responses demonstrates the consistency of this overall pattern. Table 1 compares matched departments, with employees doing equivalent jobs at Scunthorpe (8-hour working in both 1999 and 2002) and Teesside ( 8 hours in 1999, 12 hours in 2002). In each of the Scunthorpe examples, satisfaction both with overall hours of work and particularly the rota pattern, declined between 1999 and 
TABLE 1

8- and 12-Hour Working and Changes in Satisfaction ${ }^{\mathrm{a}}$ with Working Hours and Rota Pattern. Matched Departmental Comparison, 1999 and 2002 Surveys ${ }^{\text {b }}$

\begin{tabular}{|c|c|c|c|c|c|}
\hline & \multicolumn{2}{|c|}{1999 survey } & \multicolumn{3}{|c|}{2002 survey } \\
\hline & Mean & s.d. & Mean & s.d. & $t$-value $e^{\mathrm{d}}$ \\
\hline \multicolumn{6}{|c|}{ Raw materials preparation } \\
\hline \multicolumn{6}{|c|}{ Scunthorpe coke ovens $\left(N=52 / 35^{\circ}\right)$} \\
\hline Hours you work & 3.35 & 1.05 & 3.51 & 1.29 & -0.668 \\
\hline Current rota pattern & 3.14 & 1.47 & 3.74 & 1.65 & -1.785 \\
\hline \multicolumn{6}{|c|}{ Teesside coke ovens $(N=53 / 54)$} \\
\hline Hours you work & 4.00 & 1.26 & 3.31 & 1.31 & $2.756^{*}$ \\
\hline Current rota pattern & 4.15 & 1.50 & 2.70 & 1.11 & $5.544 * * *$ \\
\hline \multicolumn{6}{|l|}{ Ironmaking } \\
\hline \multicolumn{6}{|c|}{ Scunthorpe blast furnaces $(N=96 / 59)$} \\
\hline Hours you work & 3.28 & 1.15 & 3.42 & 1.00 & -0.786 \\
\hline Current rota pattern & 2.82 & 1.22 & 3.58 & 1.49 & $-3.429 * * *$ \\
\hline \multicolumn{6}{|c|}{ Teesside blast furnace $(N=57 / 30)$} \\
\hline Hours you work & 3.72 & 0.96 & 3.07 & 1.01 & $2.957 * *$ \\
\hline Current rota pattern & 3.75 & 1.56 & 2.55 & 1.02 & $3.754 * * *$ \\
\hline \multicolumn{6}{|c|}{ Steelmaking } \\
\hline \multicolumn{6}{|c|}{ Scunthorpe BOS plant $(N=116 / 80)$} \\
\hline Hours you work & 3.45 & 1.11 & 4.11 & 1.38 & $-3.734 * * *$ \\
\hline Current rota pattern & 3.16 & 1.18 & 4.53 & 1.85 & $-6.315^{* * *}$ \\
\hline \multicolumn{6}{|c|}{ Teesside BOS plant $(N=87 / 61)$} \\
\hline Hours you work & 4.03 & 1.02 & 3.23 & 1.51 & $3.877^{* * *}$ \\
\hline Current rota pattern & 4.39 & 1.52 & 2.75 & 1.53 & $6.422 * * *$ \\
\hline \multicolumn{6}{|c|}{ Steel casting } \\
\hline \multicolumn{6}{|c|}{ Scunthorpe concast $(N=116 / 46)$} \\
\hline Hours you work & 3.54 & 1.18 & 4.52 & 1.59 & $-4.290 * * *$ \\
\hline Current rota pattern & 3.11 & 1.25 & 4.87 & 2.00 & $-6.736^{* * *}$ \\
\hline \multicolumn{6}{|c|}{ Teesside concast $(N=74 / 77)$} \\
\hline Hours you work & 3.96 & 1.32 & 3.66 & 1.67 & 1.208 \\
\hline Current rota pattern & 4.35 & 1.87 & 3.28 & 1.92 & $3.472 * * *$ \\
\hline \multicolumn{6}{|c|}{ Steel finishing } \\
\hline \multicolumn{6}{|c|}{ Scunthorpe Medium Section Mill $(N=128 / 74)$} \\
\hline Hours you work & 3.69 & 1.15 & 3.69 & 1.37 & 0.021 \\
\hline Current rota pattern & 3.66 & 1.50 & 3.78 & 1.71 & -0.553 \\
\hline \multicolumn{6}{|c|}{ Teesside Beam Mill $(N=143 / 124)$} \\
\hline Hours you work & 3.52 & 1.03 & 3.03 & 1.28 & $3.473 * * *$ \\
\hline Current rota pattern & 3.40 & 1.48 & 2.43 & 1.41 & $5.399 * * *$ \\
\hline
\end{tabular}

a Responses measured on a 7-point scale ranging from 'extremely satisfied' $=1$ to 'extremely dissatisfied' $=7$.

${ }^{b}$ The Scunthorpe departments moved from 4-shift/8-hour working to 5-shift/8-hour working between the survey dates. Teesside departments moved from 4-shift/8-hour working to 5 -shift/ 12-hour working between the survey dates.

${ }^{c}$ Sample sizes shown are the number of respondents to the 1999 and 2002 surveys from the individual departments.

d 1999 respondents coded 0, 2002 respondents coded 1.

* $p<0.05$; ** $p<0.01$;** $p<0.001$. 
2002 (with one partial exception in the Medium Section Mill where satisfaction with working hours remained unchanged). This decline was particularly evident in the ironmaking, steelmaking and steel casting areas. In contrast, at Teesside, all areas of the process, from the handling of raw materials through the finishing mills, recorded highly significant increases in satisfaction with the shift rota between the two survey periods, with only slightly less marked increases in satisfaction with overall hours of work.

The change to the 5-shift rota was seen to be much less satisfactory for workers at Scunthorpe, continuing to work the 8-hour shift length (see Table 1). Interviews and survey comments highlighted the new rota system as a perceived major disadvantage associated with teamworking. The change to a 5-shift system was widely perceived (at both plants) to have created much greater rigidity for employees, particularly in their lack of discretion over the timing of holidays, compared to the previous 4-shift system. As one respondent from Scunthorpe put it in an open-ended question at the end of the 2002 survey: 'alteration of shift patterns for the worse. No consultation with shopfloor. Forced now to have rostered holidays - no flexibility'. We noted earlier that a previous study of steelworkers in North America had identified the significance of working time discretion for overall job satisfaction (see Berg 1999). Steelworkers at the Scunthorpe plant appear to have felt that they were subject to a much more restrictive rota pattern under teamworking, which was a source of widespread dissatisfaction.

In contrast, at the Teesside plant, the increase in satisfaction in 2002, both with overall hours of work and particularly the rota pattern, was evident in every area of production that had moved to 12-hour working. In connection with this, employees commented mainly on the additional non-working time that the shift pattern generated. Comments such as 'more time off with family' (Blast Furnace employee, Teesside) were frequently made, with the 18-day rest period particularly valued. Indeed, some employees commented on their ability to extend this further. One Teesside employee for example (working in the Slabyard department) noted his ability to accrue almost a month-long break through swapping shifts with colleagues at the start and finish of his 18-day break: 'I swap regularly; I swap my four days on so I have [a] 26 [day break]'.

The effect of the 12-hour working at Teesside to generate more nonworking days was seen as a major factor offsetting the greater rigidity of the 5-shift system. As a union representative and negotiator in the Teesside Concast department commented,

OK we lost the flexibility of having your holidays when you want ... but certainly my view and the majority of the people out there [in the department] was the fact that if you're at work you get your hours in while you're here and then benefit by the extra time off. The majority were for it, probably 65 per cent 35 per cent split, but since the introduction [of 12-hour working] that has increased. You might still get 15 per cent of people who say 'I don't like 12 hours, never got used to it'. Whether they'd go back [to 8-hour working] is another issue. 
While the vast majority of the Teesside plant had moved to 12-hour shifts with the introduction of teamworking, not every department had done so. Union branch ballots were held in all the Teesside departments over the shift length issue and one, Burden Preparation, voted to continue working 8-hour shifts. Burden Preparation is frequently an extremely physical job with spillages of raw materials from conveyor belts having to be manually shovelled back on to the belts, often in difficult, cramped conditions. The nature of the job discouraged workers in that department from supporting 12-hour shiftworking. This department therefore usefully provided an opportunity to check that the differences we were identifying between those on 8- and 12hour shifts were genuine, rather than reflecting a more general site difference. Comparing employees at the Teesside Burden Preparation department with those undertaking other pre-ironmaking work at the same plant, but who had moved on to 12-hour working (for example those working at the Teesside Coke Ovens department) revealed that, in 1999 there were no differences between these two departments in relation to satisfaction with rota pattern $(t=-1.22, p=\mathrm{n} . \mathrm{s}$.), with 44 per cent satisfied at Teesside Burden Preparation and 33 per cent satisfied at Teesside Coke Ovens. In 2002, 74 per cent of employees at Teesside Coke Ovens that had moved to 12 hours were satisfied with their rota pattern compared to 49 per cent satisfied at Teesside Burden Preparation remaining on 8 hours, with Coke Oven employees significantly more satisfied than Burden Preparation employees $(t=4.19, p<0.001)$. Further, there were no significant differences, either in 1999 or 2002, with regard to satisfaction with the rota pattern between the responses of those at the Teesside Burden Preparation department and their Burden Preparation counterparts at Scunthorpe (also on 8-hour shifts at both time periods). These results therefore gave support to the veracity of the identified differences between those working the different shift length patterns at the two plants.

In order to examine further the findings reported in Table 1, multivariate analyses were employed to test the overall findings in terms of compositional changes between the two survey times and the two sites. In order to do this, a series of ordinary least squared regressions were computed, the results of which are shown in Table $2 .^{1}$ Satisfaction with hours and satisfaction with rota pattern were the dependent variables, whereas age and tenure as well as a number of dummy variables representing survey time, site, 11 job grades (the 12th job grade was not included as this was used as a control variable for other job grade dummy variables), and interaction between survey time and site were the independent variables. For each dependent variable, two regressions were computed: one without the interaction effect and another with the interaction effect. The results show that in each set, the dummy variables representing survey time (and location) are not significant (models 1a and 1b), which shows the opposing satisfaction patterns between 1999 and 2002. However, in the second regression sets where the interaction effects between time and location are entered (models $2 \mathrm{a}$ and $2 \mathrm{~b}$ ), these were significant (the negative signs are due to the reverse order of the satisfaction scores), 


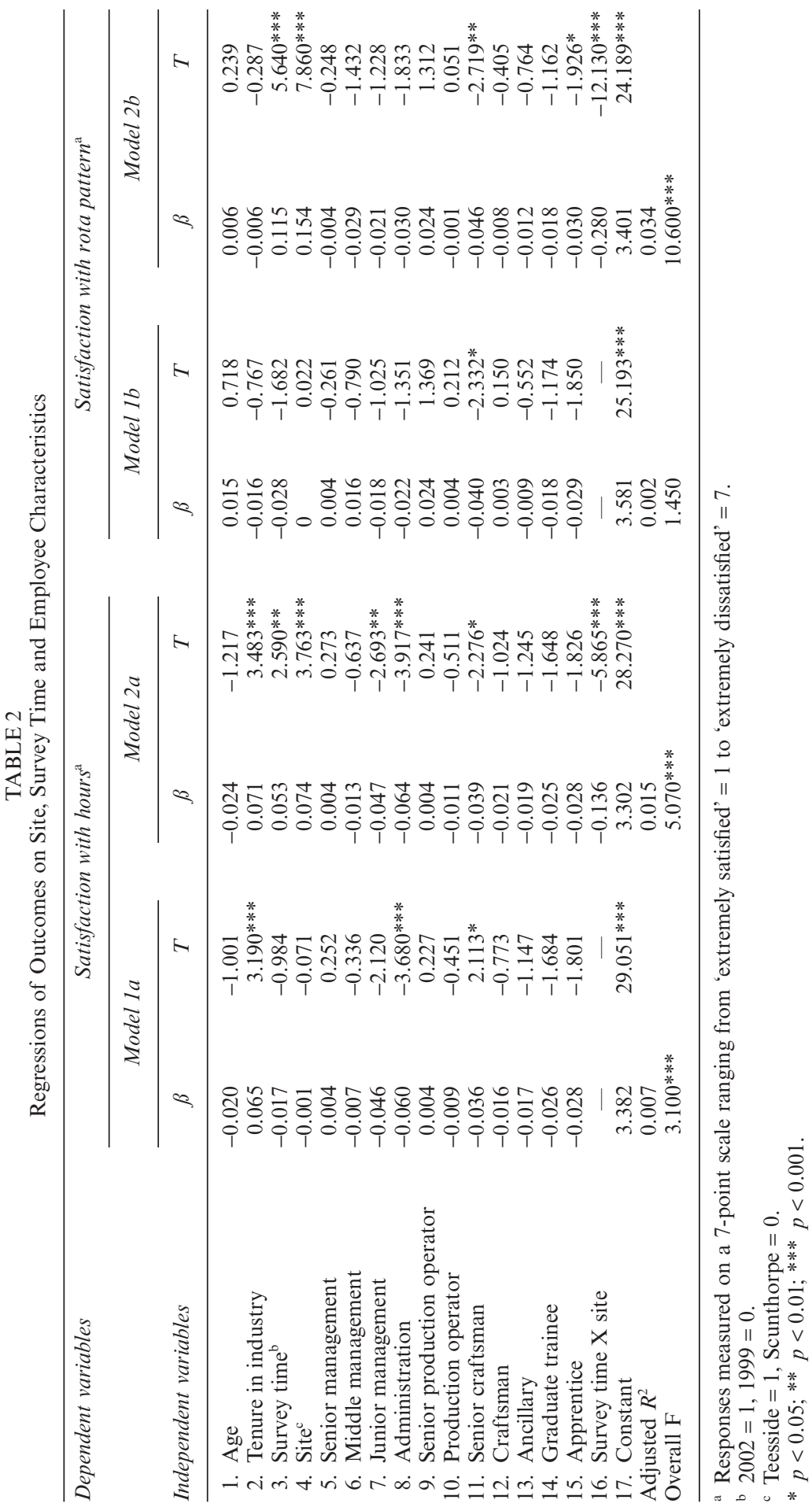


denoting that the level of satisfaction with both hours and the rota pattern is higher for Teesside (the plant with the value of 1 in the dummy variable). This is consistent with the findings reported earlier. ${ }^{2}$

\section{The Differences in Attitude to 12-Hour Working at the Two Plants}

One of the intriguing questions arising from the pattern of results is that, given the popularity of the 12-hour pattern of working at one plant (Teesside), why had it received apparently so little support at the other plant (Scunthorpe). Our evidence on this derives from interview responses and the attitude survey, and three factors in particular were highlighted. First, the very vocal opposition to 12 -hour working by the trade union convenor at the Scunthorpe plant was prominent. His view was that 12 -hour working was 'a step in the wrong direction' in the working conditions of steelworkers. As he also commented in one interview,

The 12-hour working is not here at Scunthorpe ... I think it brings its own problems both with the family who you never see, you're either working or sleeping for those four days ... Certainly I don't think anyone can work to the full extent of their abilities for that duration of time. I do question whether or not it becomes a safety issue working 12 hours at a stretch.

Other interviews with managers and union representatives at Scunthorpe reinforced the view that the union convenor's opposition to 12-hour working became established as a generally held position. There was certainly no evidence in the interviews or survey comments that there was any groundswell of opinion at Scunthorpe in support of 12-hour working. This is also evidenced by the fact that there were no union branch ballots held on the question of 8- or 12-hour working at Scunthorpe. In contrast, at Teesside, each department held a union ballot on the shift length question; in all but the Burden Preparation area these returned large majorities in favour of moving to the longer shift length.

A second explanation offered to account for the lack of support for 12hour working at Scunthorpe was put forward by several union representatives at Teesside: that the Scunthorpe employees had not experienced the 12-hour pattern 'so don't know what they're missing'. Of course, this does not explain the support from the outset for 12-hour working at Teesside, where employees voted in favour of the 12-hour schedule without having experienced it. Yet, an implication of these comments is that if 12-hour working was introduced at Scunthorpe, it would find much more widespread support than was currently evident.

The third explanation is that when the issue was raised, union representatives at Scunthorpe agreed with managers that 12-hour working could damage plant productivity as workers tired on shift, and recurring four-day breaks with a prolonged 18-day rest period could encourage workers to feel less responsibility for plant performance. The moderate unions at Scunthorpe had worked closely with managers to introduce teams, improve productivity 
and secure the future of the plant, reflected in a more positive industrial relations climate at Scunthorpe than Teesside. ${ }^{3}$ In contrast, the relatively militant union at Teesside demanded improved terms and conditions in return for teamworking and the increased work pressure it would entail, with 12hour working an important side payment to reach teamworking agreements. Employees at Teesside were not convinced that 12-hour working would harm productivity or affect long-term management decisions on the future of the plant.

\section{Work Pressure}

As well as eliciting views on the working time changes in the employee surveys, at both time periods we measured perceived work pressure and attitudes to the introduction of teamworking. On work pressure, we were interested in whether those working the more extended shift period reported higher levels of fatigue, or alternatively whether the longer workshift was accompanied by a more relaxed work tempo (particularly because management did not work the 12-hour rota). Our findings contrast with those of Appelbaum et al. (2000) who reported no evidence of increased job stress in steel as a result of participation in self-directed work teams or off-line problem solving teams. Comparing survey responses before and after the introduction of teamworking, we found first that employees generally (irrespective of their plant or department) reported a significant increase in work pressure. In particular, 44 per cent of workers in the overall sample in 1999 said that they were 'always' or 'mostly' 'working to tight deadlines' compared to 48 per cent in $2002(t=3.248, p<0.001), 33$ per cent were 'under a great deal of pressure' in 1999 rising to 48 per cent in $2002(t=4.500, p<0.001)$, and 20 per cent in 1999 'rarely' or 'never' 'had enough time to get the work done' compared to 25 per cent in $2002(t=-4.086, p<0.001)$. Employees were also more likely to report being 'physically tired' (22 per cent in 1999 and 30 per cent in 2002) and 'mentally tired' (33 per cent in 1999 and 42 per cent in 2002) ( $t=6.183, p<0.001$ and $t=6.701, p<0.001$, respectively). The interviews with managers and union representatives confirmed this sense of a more intensive work regime, primarily reflecting the substantial reduction (21 per cent) in employment levels that had accompanied teamworking, leaving those remaining in the different production areas to cover a larger number and range of tasks.

In the first survey in 1999, there were no significant differences between the two plants on any of the work pressure items. By 2002, however, on four of the six aspects of work pressure we measured, those working 12-hour shifts at the Teesside plant were more likely to report work pressure, compared to their counterparts on 8-hour shifts at the Scunthorpe plant (Table 3). Thus, while the 12-hour rota was favoured by most employees working it, compared to their counterparts on 8-hour shifts (see above), this was not because the 12-hour pattern was experienced as a less pressured work routine. On the contrary, among this sample of employees, the longer shifts were more likely 
TABLE 3

Comparison of Work Pressure ${ }^{\text {a }}$ Reported by Employees on 8-Hour and 12-Hour Shifts (2002 Survey)

\begin{tabular}{|c|c|c|c|c|c|}
\hline & \multicolumn{2}{|c|}{$\begin{array}{l}\text { 8-hour shifts } \\
(N=804)\end{array}$} & \multicolumn{3}{|c|}{$\begin{array}{l}\text { 12-hour shifts } \\
(N=365)\end{array}$} \\
\hline & Mean & s.d. & Mean & s.d. & $t$ value ${ }^{\mathrm{b}}$ \\
\hline Working at high speed & 2.95 & 0.90 & 2.69 & 0.87 & $4.62 * * *$ \\
\hline Working to tight deadlines & 2.60 & 0.90 & 2.36 & 0.85 & $4.16^{* * *}$ \\
\hline Working under great deal of pressure & 2.72 & 0.91 & 2.58 & 0.83 & $2.61 * *$ \\
\hline Enough time to get work done & 2.80 & 0.91 & 2.76 & 0.82 & 0.65 \\
\hline Physically tired & 2.66 & 0.87 & 2.54 & 0.86 & $2.23 * *$ \\
\hline Mentally tired & 2.67 & 0.96 & 2.57 & 0.87 & 1.61 \\
\hline
\end{tabular}

a Responses measured on a 5-point scale ranging from 'always' $=1$ to 'never' $=5$.

${ }^{b}$ Respondents on 8-hour shifts coded 0 , those on 12-hour shifts coded 1 .

** $p<0.01 ; * * *<0.001$.

to be accompanied by a perceived increase in work pressure, compared to the shorter shifts.

Our confidence increases in attributing greater work pressure to the longer shifts when we consider workforce reductions. The total workforce reduction across both sites of 21 per cent was an important factor in the increase in work pressures between 1999 and 2002. Manning was reduced by 13 per cent on average in Teesside departments and 25 per cent in Scunthorpe departments, and the workforce reduction agreed as part of teamworking negotiations was greater in every Scunthorpe department compared to the matched Teesside department, except in one department where it was identical. Without the change in working time we would therefore expect a more significant increase in work pressure in Scunthorpe departments because of greater demanning. As employees reported a greater increase in pressure in Teesside departments, we conclude that working 12-hour shifts contributed significantly to work intensification under teamworking.

\section{Attitudes to Teamworking}

Notwithstanding a greater increase in work pressure at Teesside, employee support for teamworking in 2002, following its introduction, was significantly higher at the Teesside plant with 46 per cent in favour of teamworking than at the Scunthorpe plant with 34 per cent in favour (Table 4). At Scunthorpe, employees were statistically less favourably disposed to teamworking in 2002 than in 1999 when 48 per cent were in favour, whereas the level of support for teamworking at the Teesside plant was identical with 46 per cent in favour at the two time periods. As a result, in 1999, it was respondents at the Scunthorpe plant who were significantly more favourably disposed to teamworking than their Teesside counterparts $(t=2.65, p<0.01)$, a pattern reversed by $2002(t=-4.813, p<0.001)$. 
TABLE 4

Employees' Overall Attitude to Teamworking ${ }^{\mathrm{a}}$ and Job Satisfaction ${ }^{\mathrm{b}} 1999$ and 2002 Surveys

\begin{tabular}{|c|c|c|c|c|c|}
\hline & \multicolumn{2}{|c|}{1999 survey } & \multicolumn{3}{|c|}{2002 survey } \\
\hline & Mean & s.d. & Mean & s.d. & $t$ value $^{\mathrm{c}}$ \\
\hline \multicolumn{6}{|l|}{ Attitude to teamworking } \\
\hline Scunthorpe & 2.62 & 1.16 & 3.07 & 1.11 & $-9.35^{* * *}$ \\
\hline Teesside & 2.75 & 1.20 & 2.78 & 1.13 & -0.51 \\
\hline \multicolumn{6}{|l|}{ Job satisfaction } \\
\hline Scunthorpe & 3.90 & 1.34 & 4.09 & 1.39 & $-3.53^{* * *}$ \\
\hline Teesside & 4.20 & 1.34 & 4.09 & 1.38 & -1.70 \\
\hline
\end{tabular}

${ }^{a}$ Responses on a 5-point scale ranging from 'strongly in favour' $=1$ to 'strongly against' $=5$.

b Responses on a 7-point scale ranging from 'extremely satisfied' $=1$ to 'extremely dissatisfied' $=7$.

c 1999 respondents coded 0, 2002 respondents coded 1.

*** $p<0.001$.

This pattern of the Scunthorpe respondents indicating a declining support for teamworking compared to their Teesside counterparts is also evident across the different departments involved in iron and steelmaking (Table 5). In the Scunthorpe departments remaining on 8-hour shifts, all but one (the Scunthorpe Medium Section Mill) recorded a significant decline in support for teamworking. In contrast, as Table 5 shows, the Teesside departments (where employees moved from 8- to 12-hour working) showed no similar decline (and one department, the Teesside Beam Mill, recorded a significant increase in support for teamworking).

In interviews with union representatives and managers, it was evident that a major factor influencing overall attitudes of employees to the introduction of teamworking was seen to be their views on the accompanying working time changes. Other issues were noted in the interviews (on aspects of pay and manning levels for instance), but the working time issue was the one that was by far the most prominent in interview comments. For many union representatives and employees at Teesside, the introduction of the 12-hour pattern clearly represented an important compensation or 'side payment' for teamworking, making other aspects of the change (such as the more intensive work regime) more palatable. As one Teesside employee put it '[the job has] got worse due to a heavier work-load, but having more time off makes it bearable'. At Scunthorpe on the other hand, the greater restrictions accompanying the 5-shift system were regarded as a major and uncompensated drawback in the move to teamworking.

Scunthorpe employees were initially more favourably disposed towards teamworking in 1999 because of the tradition of industrial relations cooperation at the site. Employees believed managers would work with unions to ensure teamworking partly reflected the interests of employees. This cooperative tradition created a more positive industrial relations climate and the 
TABLE 5

8- and 12-Hour Working and Changes in Overall Attitude to Teamworking ${ }^{a}$. Matched Departmental Comparison, 1999 and 2002 Surveys $^{\text {b }}$

\begin{tabular}{|c|c|c|c|c|c|}
\hline & 1999 & & & $002 s t$ & \\
\hline & Mean & s.d. & Mean & s.d. & $t$ value $^{\mathrm{d}}$ \\
\hline Raw materials preparation & & & & & \\
\hline Scunthorpe coke ovens $(N=51 / 33)^{\mathrm{c}}$ & & & & & \\
\hline Overall attitude to teamworking & 2.80 & 1.20 & 3.36 & 0.99 & $-2.23^{*}$ \\
\hline Teesside coke ovens $(N=52 / 47)$ & & & & & \\
\hline Overall attitude to teamworking & 2.98 & 1.21 & 3.04 & 1.02 & -0.27 \\
\hline Ironmaking & & & & & \\
\hline Scunthorpe blast furnaces $(N=94 / 5$ & & & & & \\
\hline Overall attitude to teamworking & 2.87 & 1.27 & 3.67 & 1.06 & $-3.96 * * *$ \\
\hline Teesside blast furnace $(N=57 / 26)$ & & & & & \\
\hline Overall attitude to teamworking & 2.84 & 1.26 & 2.69 & 1.09 & 0.52 \\
\hline Steelmaking & & & & & \\
\hline Scunthorpe BOS plant $(N=116 / 74)$ & & & & & \\
\hline Overall attitude to teamworking & 2.53 & 1.14 & 3.34 & 1.23 & $-4.60 * * *$ \\
\hline Teesside BOS plant $(N=84 / 56)$ & & & & & \\
\hline Overall attitude to teamworking & 2.89 & 1.27 & 2.95 & 1.20 & -0.25 \\
\hline Steel casting & & & & & \\
\hline Scunthorpe concast $(N=111 / 44)$ & & & & & \\
\hline Overall attitude to teamworking & 2.45 & 1.23 & 3.14 & 1.09 & $-3.22 * *$ \\
\hline Teesside concast $(N=74 / 73)$ & & & & & \\
\hline Overall attitude to teamworking & 2.54 & 1.22 & 2.92 & 1.24 & -1.86 \\
\hline Steel finishing & & & & & \\
\hline Scunthorpe Medium Section Mill ( $\Lambda$ & $29 / 69)$ & & & & \\
\hline Overall attitude to teamworking & 2.81 & 1.05 & 3.03 & 1.06 & -1.42 \\
\hline Teesside Beam Mill $(N=143 / 110)$ & & & & & \\
\hline Overall attitude to teamworking & 2.70 & 1.18 & 2.33 & 1.14 & $2.52 *$ \\
\hline
\end{tabular}

a Responses measured on a 5-point scale ranging from 'strongly in favour' $=1$ to 'strongly against' $=5$.

$\mathrm{b}$ The Scunthorpe departments moved from 4-shift/8-hour working to 5-shift/8-hour working between the survey dates. Teesside departments moved from 4 -shift/8-hour working to 5 -shift/ 12-hour working between the survey dates.

${ }^{c}$ Sample sizes shown are the number of respondents to the 1999 and 2002 surveys from the individual departments.

d 1999 respondents coded 0, 2002 respondents coded 1.

$* p<0.05 ; * * \quad p<0.01 ; * * * \quad p<0.001$.

expectation that managers would respect the union's goals, negotiate in good faith and with a sense of fairness. However, in difficult economic circumstances, Scunthorpe managers could not offer significant increases in earnings in return for teamworking and employees felt unrecompensed for change. In contrast, the unions at Teesside believed militancy was required to force managers to share the benefits of productivity gains through teamworking. Employees at Teesside refused to accept teamworking agreements until managers made concessions and with limited scope to increase earnings, managers agreed to 12-hour shifts. 


\section{Job Satisfaction}

If the compressed work schedule compensates for the increased intensity of teamworking, we would expect workers in the plant with such schedules to experience greater job satisfaction. Comparing survey responses before and after the introduction of teamworking, we found that overall employees reported a decline in job satisfaction with 45 per cent satisfied in 1999 and 43 per cent satisfied in $2002(t=-2.295, p<0.05)$. In 1999, prior to the changes, Scunthorpe employees were significantly more satisfied (49 per cent were satisfied) with their job compared to employees at Teesside (38 per cent were satisfied) $(t=5.54, p<0.001)$. However, in 2002, no significant difference in job satisfaction was reported between the two sites with 43 per cent satisfied at both sites. Table 4 shows that job satisfaction had improved at Teesside between 1999 and $2002(t=1.7, p=0.089)$ whereas job satisfaction declined significantly at Scunthorpe $(t=-3.53, p<0.001)$. Compressing the work schedule had improved job satisfaction when teamworking was introduced compensating employees for increased work pressure with more time away from work.

\section{Conclusion}

In studying employee responses to the introduction of teamworking at the two plants, it was evident that accompanying working time changes were a key component of overall responses to the work changes taking place. At the Scunthorpe plant, which introduced the 5-shift system while retaining an 8hour shift pattern, there was widespread feeling that teamworking had resulted in people working harder, with fewer people in each area and with a more restrictive shift system, and that no compensatory concessions had been gained. At Teesside, on the other hand, where there was support for negotiating a change to 12 -hour working, the new shift pattern, particularly the additional non-work days it yielded, appears to have represented significant compensation for the greater effort required under teamworking.

Several broader issues are raised by this study and are worthy of further investigation. First, the potential significance of working time for employee responses to broader programmes of work organization change (in this case centred on teamworking) has been highlighted. Attitudes to the different rota patterns underline the importance of the arrangement of working hours, as well as their overall quantity, for employees. Second, the pattern of results indicates that in this case of experiencing a more arduous job, a compressed work week provided a desirable work-life balance for the Teesside workers, by offsetting the harder work regime with fewer shifts and more non-working days. Given the potential clash of employees seeking better work-life balance, and employers seeking to extend operating/opening times, compressed schedules warrant further consideration as a means of reconciling these different labour supply and demand pressures. For managers and unions, compressed work schedules offer the potential for mutual gains from 'high performance' 
work practices where employers require greater work intensity, but the economic conditions prevent a significant increase in earnings to recompense employees. Employees may be satisfied with harder work if the timing of work is more convenient.

Third, the marked difference in desire for 12-hour working at the two plants underlines the need to take contextual factors into account when exploring employee preferences in future debates over working time and work-life balance. Finally, the present study was limited by its single-sex samples (there were no women production workers at either site during the period of the study). Thus, a useful extension of the study would be to examine shift preferences not only among different occupational groups, but particularly among those groups where women as well as men are fully represented.

Final version accepted 18 May 2005.

\section{Acknowledgements}

Our thanks to Francis Green, the three anonymous referees and to Ignace $\mathrm{Ng}$ for his advice on our data analysis.

\section{Notes}

1. There could be limitations to ordinary least squared (OLS) regression in situations where the dependent variable is a discrete number. For example, it could lead to low $R^{2}$ and could lead to estimated values of the dependent variable that is outside its range (Kennedy 1979). In order to account for this and convert the dependent variable into an interval measure, we ran the regressions with $\log$ of the dependent variables. The results were almost identical to the OLS results reported in Table 2.

2. In addition, in order to show the full effect of time and site on satisfaction, we used the following calculations based on the results reported in Table 2. Since time is a dummy variable coded 1 for 2002 and 0 for 1999, and site is also a dummy variable coded 1 for Teesside and 0 for Scunthorpe, the resulting overall effect involving interaction term applies only to 2002 Teesside (for an explanation of this approach, see Cohen and Cohen 1983). To calculate the estimated coefficient for 2002 Teesside, we have taken the 1999 Teesside coefficients from Table 2 plus the interaction term coefficients. For the satisfaction with hours dependent variable, the overall effect is $(0.074)+(-0.136)=-0.062$. For satisfaction with rota pattern the same coefficient is calculated as $(0.154)+(-0.28)=-0.126$. These are consistent with the results reported above.

3. Industrial relations climate is the average of scores for four items taken from Dastmalchian et al. (1991) included on employee surveys undertaken in 1999 and 2002: 'unions and management work together to make this a better place to work', 'unions and management have respect for each other's goals', 'in this department, negotiations take place in an atmosphere of good faith' and 'a sense of fairness is associated with union management dealings in this department'. Each was measured on a 5-point scale from 'strongly agree' $(=1)$ to strongly disagree $(=5)$. A 
reliability test indicated the items could be combined (1999 alpha $=0.87,2002$ alpha $=0.91)$. In both $1999(t=6.05, p<0.001)$ and $2002(t=3.1, p<0.01)$ Scunthorpe employees reported a more positive industrial relations climate than counterparts at Teesside.

\section{References}

Anderson-Connolly, R., Grunberg, L., Greenberg, E. S. and Moore, S. (2002). 'Is lean mean? Workplace transformation and employee well-being'. Work, Employment and Society, 16: 389-413.

Andries, F., Kompier, M. and Smulders, P. (1996). 'Do you think that your health or safety are at risk because of your work? A large European study on psychological and physical work demands'. Work and Stress, 10: 104-18.

Appelbaum, E., Bailey, T., Berg, P. and Kalleberg, A. (2000). Manufacturing Advantage. Ithaca: Cornell University/ILR Press.

Baker, A., Roach, G., Ferguson, S. and Dawson, D. (2003). 'The impact of different rosters on employee work and non-work time preferences'. Time and Society, 12: 315-32.

Berg, P. (1999). 'The effects of high performance work practices on job satisfaction in the United States steel industry'. Relations Industrielles, 54: 111-35.

Bluestone, B. and Rose, S. (2000). 'The enigma of working time trends'. In L. Golden and D. M. Figart (eds.), Working Time: International Trends, Theory and Policy Perspectives. London: Routledge, pp. 21-37.

Blyton, P. (1994). 'Working hours'. In K. Sisson (ed.), Personnel Management (2nd edn). Oxford: Blackwell, pp. 495-526.

(1995). The Development of Annual Working Hours in the United Kingdom. Geneva, Switzerland: International Labour Organisation.

Campbell, I. (2002). 'Extended working hours in Australia'. Labour and Industry, 13: 91-110.

Casey, B., Metcalf, H. and Millward, N. (1997). Employers' Use of Flexible Labour. London: Policy Studies Institute.

Clark, A. and Oswald, A. (1996). 'Satisfaction and comparison income'. Journal of Public Economics, 61: 359-81.

Cohen, J. and Cohen, P. (1983). Applied Multiple Regression/Correlation Analysis for Behavioral Sciences (2nd edn). Hillsdale, NJ: Lawrence Erlbaum Associates.

Dastmalchian, A., Blyton, P. and Adamson, R. (1991). The Climate of Workplace Relations. London: Routledge.

Dex, S. (ed.) (1999). Families and the Labour Market: Trends, Pressures and Policies. London: Joseph Rowntree Foundation.

Gareis, K. C. and Chait Barnett, R. (2002). 'Under what conditions do long work hours affect psychological distress: a study of full-time and reduced-hours female doctors'. Work and Occupations, 29: 483-97.

Golden, L. and Figart, D. M. (eds.) (2000). Working Time: International Trends, Theory and Policy Perspectives. London: Routledge.

Goodale, J. G. and Aagard, A. K. (1975). 'Factors relating to varying reactions to the 4-day workweek'. Journal of Applied Psychology, 60: 33-8.

Gray, M. and Tudball, J. (2003). 'Family-friendly work practices: differences within and between workplaces'. Journal of Industrial Relations, 45: 269-91.

(C) Blackwell Publishing Ltd/London School of Economics 2005. 
Handel, M. J. and Levine, D. I. (2004). 'Editor's introduction: the effects of new work practices on workers'. Industrial Relations, 43: 1-43.

Harley, B. (2001). 'Team membership and the experience of work in Britain: an analysis of the WERS98 data'. Work, Employment and Society, 15: 721-42.

Heiler, K. (ed.) (1998). The 12 Hour Workday: Emerging Issues. Working Paper No. 51, Australian Centre for Industrial Relations Research and Training (ACIRRT), University of Sydney.

Hunter, L. W., MacDuffie, J. P. and Doucet, L. (2002). 'What makes teams take? Employee reactions to work reforms'. Industrial and Labor Relations Review, 55: 448-72.

IDS (Incomes Data Services) (2002). Annual Hours. IDS Study No. 721, London: Incomes Data Services.

Iskra-Golec, I., Folkard, S., Marek, T. and Noworol, C. (1996). 'Health, wellbeing and burnout of ICU nurses on 12 and 8-hour shifts'. Work and Stress, 10: 251-6.

Kaliterna, L. and Prizmic, Z. (1998). 'Evaluation of the survey of shiftworkers (SOS) short version of the standard shiftwork index'. International Journal of Industrial Ergonomics, 21: 259-65.

Kennedy, P. (1979). A Guide to Econometrics. Cambridge, MA: MIT Press.

Kogi, K. and Di Martino, V. G. (1995). 'Trends in the participatory process of changing shiftwork arrangements'. Work and Stress, 9: 298-304.

Latack, J. C. and Foster, L. W. (1985). 'Implementation of compressed work schedules: participation and job redesign as critical factors for employee acceptance'. Personnel Psychology, 38: 75-92.

Loudoun, R. and Harley, B. (2001). 'Industrial relations decentralisation and the growth of 12 hour shifts in Australia'. Journal of Industrial Relations, 43: 402-21.

Lowden, A., Kecklund, G., Axelsson, J. and Akerstedt, T. (1998). 'Change from 8hour to 12-hour shift: attitudes, sleep, sleepiness and performance'. Scandinavian Journal of Work and Environmental Health, 24 (suppl. 3): 69-75.

Marchington, M. (2000). 'Teamworking and employee involvement: terminology, evaluation and context'. In S. Procter and F. Mueller (eds.), Teamworking. London: Macmillan, pp. 60-80.

Milia, L. D. (1998). 'A longitudinal study of the compressed workweek: comparing sleep on a weekly rotating $8 \mathrm{~h}$ system to a faster rotating $12 \mathrm{~h}$ system'. International Journal of Industrial Ergonomics, 21: 199-207.

Mitchell, R. J. and Williamson, A. M. (2000). 'Evaluation of an 8 hours versus a 12 hours shift roster on employees at a power station'. Applied Ergonomics, 31: 83-93.

Nelson, L. and Holland, P. (2001). 'Assessing the impact of twelve hour shifts: an evaluation by ten companies and union officials'. Labour and Industry, 12: 97-113.

Noon, M. and Blyton, P. (2002). The Realities of Work (2nd edn). Basingstoke: Palgrave Macmillan.

Nord, W. R. and Costigan, R. (1973). 'Worker adjustment to the four-day week: a longitudinal study'. Journal of Applied Psychology, 58: 60-6.

Ognianova, V. M., Dalbokova, D. L. and Stanchev, V. (1998). 'Stress states, alertness and individual differences under 12-hour shiftwork'. International Journal of Industrial Ergonomics, 21: 283-91.

Parker, M. and Slaughter, J. (1994). Working Smart: A Union Guide to Participation Programs and Reengineering. Detroit: Labor Notes. 
Patterson, M. and West, M. (1998). 'People power: The link between job satisfaction and productivity'. CentrePiece, 3: 2-5.

Pierce J. L. and Dunham R. B. (1992). 'The 12-hour workday: A 48-hour, eight-day week'. Academy of Management Journal, 35: 1086-98.

Purcell, K., Hogarth, T. and Simm, C. (1999). Whose Flexibility? The Costs and Benefits of Non-Standard Working Arrangements and Contractual Relations. York: Joseph Rowntree Foundation.

Rinehart, J., Huxley, C. and Robertson, D. (1997). Just Another Car Factory: Lean Production and Its Discontents. Ithaca: ILR Press.

Ronen, S. and Primps, S. B. (1981). 'The compressed work week as organizational change: behavioral and attitudinal outcomes'. Academy of Management Review, 6: $61-74$.

Rosa, R. R. (1995). 'Extended workshifts and excessive fatigue'. Journal of Sleep Research, 4: 51-6.

Smith, L., Spelten, E. and Norman, P. (1995). 'Shiftwork locus of control: scale development'. Work and Stress, 9: 219-26.

, Folkard, S., Tucker, P. and Macdonald, I. (1998a). 'Work shift duration: a review comparing 8-hour and 12-hour shift systems'. Occupational and Environmental Medicine, 55: 217-29.

-, Macdonald, I., Folkard, S. and Tucker, P. (1998b). 'Industrial shift systems'. Applied Ergonomics, 29: 273-80.

Sparks, K., Cooper, C., Yitshak, F. and Shirom, A. (1997). 'The effects of hours of work on health: a meta-analytic review'. Journal of Occupational and Organisational Psychology, 70: 391-408.

Steijn, B. (2001). 'Work systems, quality of working life and attitudes of workers: an empirical study towards the effects of team and non-teamwork'. New Technology, Work and Employment, 16: 191-203.

Stewart, M. B. and Swaffield, J. K. (1997). 'Constraints on the desired hours of work of British men'. The Economic Journal, 107: 520-35.

Stier, H. and Lewin-Epstein, N. (2003). 'Time to work: a comparative analysis of preferences for working hours'. Work and Occupations, 30: 302-26.

Wall, T. D., Kemp, N. J., Jackson, P. R. and Clegg, C. W. (1986). 'Outcomes of autonomous work groups: a long-term field experiment'. Academy of Management Journal, 29: 280-304.

Wallace, M. (1998). 'The effects of 12 hour shifts: Recent international and Australian research'. In K. Heiler (ed.), The 12 Hour Workday: Emerging Issues. Working paper no. 51, Australian Centre for Industrial Relations Research and Training (ACIRRT), University of Sydney, pp. 15-20.

Warr, P., Cook, J. and Wall, T. (1979). 'Scales for the measurement of some work attitudes and aspects of psychological well-being'. Journal of Occupational Psychology, 52: 129-48. 